\title{
IMPLICATIONS OF FOODBORNE INFECTIOUS HEPATITIS
}

\author{
Dean O. Cliver, Ph.D.
}

IN REVIEWING the roles of milk and water in the dissemination of viruses and rickettsia infectious for humans, Brown (1) concluded that only the virus of infectious hepatitis was spread in this fashion to any significant extent. More recent reviews by Berg (2) and by Lemon (3) have suggested that food might serve as a vehicle for a variety of viruses. Among reported foodborne outbreaks of virus disease, however, infectious hepatitis predominates by a considerable margin. The following discussion attempts to relate what is known of infectious hepatitis that is germane to its transmission in foods to the more general question of foodborne viruses.

Infectious hepatitis is a distinct clinical entity, although Havens (4) stated that it was not generally recognized as such until the time of World War II. It has been reportable throughout the United States since 1954. Differential diagnosis is based on signs and symptoms associated with the disease (5), often including jaundice, and an incubation period of 15 to 50 days (6). Liver function tests may be employed for confirmation and in the detection of subclinical infections. There is good evidence to indicate that the etiologic agent is a virus which is capable of producing infection when introduced by the oral route and which is shed for considerable periods of time in the feces of infected persons. It has been stated that transmission of the agent is essentially by the intestinal-oral route, with water or food being occasionally interposed as a vehicle (5).

\section{Foodborne Outbreaks}

Although the demonstration that infectious hepatitis virus is shed in feces is in itself suggestive that the agent might be transmitted in foods in a manner analogous to the enteric pathogens, actual reports of foodborne out- breaks began to appear with regularity only in recent years. A probable foodborne outbreak of infectious hepatitis affected 69 students at Yale University in 1921 ( 7$)$. Reinterpretation of the information presented is somewhat difficult because viral hepatitis had not yet been described, and the investigation was predicated upon bacterial etiology and a relatively short incubation period. With the recognition of viral infectious hepatitis as a distinct clinical entity, the record of transmission of the disease in foods began. Reports of 15 outbreaks since 1943 in which food was the probable vehicle are summarized in table 1.

Because of the long incubation period of the disease, food could be implicated as a vehicle only by deductive methods in a number of these outbreaks. Often it was not possible to specify the particular food which carried the virus or how it might have become contaminated, yet the evidence that food was involved is quite convincing. In the Cleveland outbreak in 1944, cases were restricted to members of a fraternity who ate meals at their fraternity house, whether or not they lived there (9). Only recruits in odd-numbered platoons of several companies were affected in the California outbreak in 1962, and the even-numbered and odd-numbered platoons were distinguished only by having been fed in separate mess lines when eating lunch at the rifle range (Dr. R. D. Aach, Hepatitis Surveillance Unit, Communicable Disease Center, Public Health Service, 1963, unpublished data.)

The outbreak in Missouri City, Tex., in 1959,

Dr. Cliver is a research associate, Food Research Institute and Department of Microbiology, University of Chicago. This study was supported by grant EF-00440 from the Division of Environmental Engineering and Food Protection, Public Health Service. 
Table 1. Outbreaks of infectious hepatitis associated

\begin{tabular}{|c|c|c|c|}
\hline Location of outbreak 1 & Dates of onset & $\begin{array}{l}\text { Number } \\
\text { exposed }\end{array}$ & $\begin{array}{l}\text { Number } \\
\text { infected }\end{array}$ \\
\hline $\begin{array}{l}\text { East Lothian, Scotland (8) } \\
\text { Cleveland, Ohio }(9) \\
\text { Forsyth, Ga. }(10)\end{array}$ & $\begin{array}{l}\text { Apr. 13-May } 1,1943 \ldots \\
\text { May 26-June } 5,1944 \ldots \\
\text { May 21-June 28, 1945 } \ldots \ldots\end{array}$ & 450 & $\begin{array}{r}149 \\
24 \\
14\end{array}$ \\
\hline $\begin{array}{l}\text { Oxford College, England (11) } \\
\text { Camp Edwards, Mass. (12) }\end{array}$ & $\begin{array}{l}\text { May 22-June 10, } 1950 \ldots \\
\text { Oct. } 25-\text { Nov. } 29,1951 \ldots\end{array}$ & 150 & $\begin{array}{l}49 \\
15\end{array}$ \\
\hline $\begin{array}{l}\text { College in South Carolina (13) } \\
\text { Mangakino, New Zealand (14) }\end{array}$ & $\begin{array}{l}\text { Oct. 4-Nov. 18, 1952 } \ldots \ldots \\
\text { About July 20, 1957 } \ldots \ldots\end{array}$ & $\begin{array}{l}2,290 \\
\text { n.s }\end{array}$ & $\geq 222$ \\
\hline Mediterranean Fleet, U.S. Navy (15) & Jan. 19-Feb. 22, 1959 & n.s....... & 156 \\
\hline $\begin{array}{l}\text { Adjacent grade and high schools, Missouri City, Tex. } \\
(16) \text {. } \\
\text { Psychiatric institution, New Jersey (17) }\end{array}$ & $\begin{array}{l}\text { Sept. 27-Oct. 6, } 1959 \\
1960\end{array}$ & $\geq 121$ & $\begin{array}{l}21 \\
19\end{array}$ \\
\hline Office building, St. Paul, Minn. (18) & June $2-20,1961 \ldots$ & n.s....... & 20 \\
\hline Naval base, Florida (19) & Nov. 18-Dec. 13, 1961 $\ldots \ldots$ & $162 \ldots \ldots$ & 22 \\
\hline Jewish Hospital of St. Louis, Mo. (20) & July 21-Aug. 12, 1962 $\ldots$ & n.s._...... & 14 \\
\hline Military base, California (unpublished data) & Oct. $28-$ Nov. 18,1962 & $1,477 \ldots$ & 49 \\
\hline $\begin{array}{l}\text { American dependents' school, Bushey Hall, England } \\
\text { (unpublished data). }\end{array}$ & Nov. 29, 1962-Jan. 9, 1963_.-- & $598 \ldots \ldots$ & 44 \\
\hline
\end{tabular}

1 Numbers in parentheses are references.

Note: n.s. = not specified.

was foodborne in only a limited sense: the virus apparently had been disseminated on compartmented cafeteria trays in which food was served, because the source person was reported not to have handled food (16). I have included the Missouri City outbreak because the epidemiologic pattern was that of a foodborne outbreak and because it illustrates the significance of infectious hepatitis in kitchen personnel who may not handle food directly. Of the seven foodhandlers and kitchen workers implicated as having source cases, one had a subclinical infection, two handled foods only during the incubation period of the disease, and four worked for various periods of time after onset of symptoms, which included jaundice in two of these four persons.

The majority of the foods implicated had been cooked very little or not at all. One notable exception was the roast pork incriminated in the Bushy Hall, England, outbreak in 1963. The pork had been roasted thoroughly, cooled, and boned by hand by a cook who was jaundiced and who subsequently sliced and warmed the meat on a steamtable before serving (Dr. J. W. Mosley, chief, Hepatitis Surveillance Unit, Communicable Disease Center, 1963, unpublished data). It appears that even a thoroughly cooked food may become a hazard if it is handled just before serving or if it is served on a contaminated dish or tray.

Thus, the only obvious distinction of raw foods is that virus introduced at any point in handling may reach the consumer in infectious form, while thoroughly cooked foods may carry infectious virus to the consumer only under the circumstances described previously. However, reports of some of these outbreaks indicate that food histories taken in the course of the investigation have included only foods which have not 


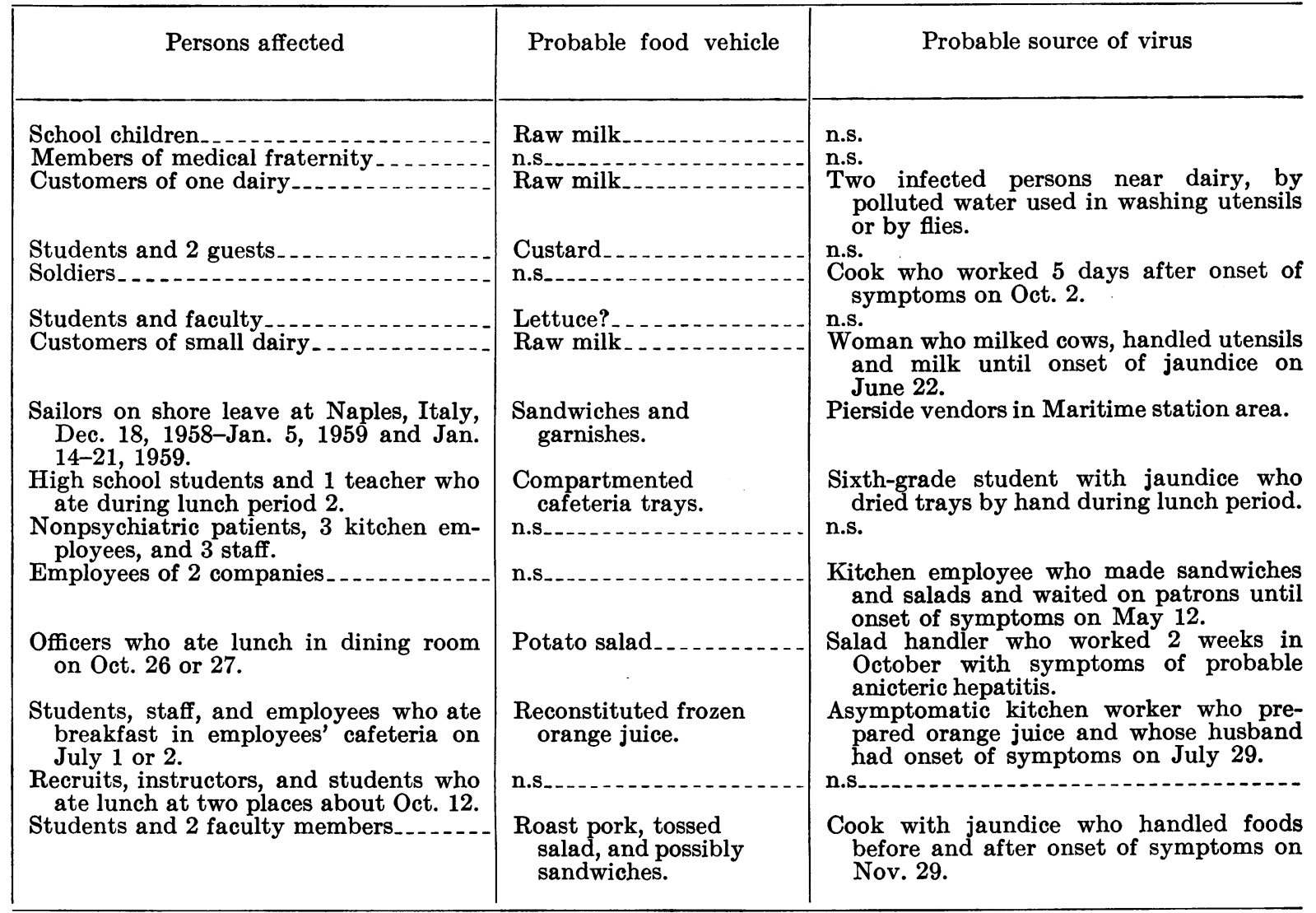

been cooked. A food implicated by such an investigation is probably that which carried the virus; but when none of the foods considered can be incriminated, there is a distinct possibility that a cooked food has been the vehicle. It is not possible to estimate the extent to which the list of foods appearing in table 1 may have been biased in this fashion, but the question merits further consideration.

Some of the investigators cited also included a search for persons with secondary or contact cases resulting from the outbreak. None were found in the 1944 Cleveland outbreak (9), but 2 of the 14 persons in the 1945 outbreak in Forsyth, Ga., might have had secondary rather than foodborne infections (10). Three persons with contact cases, in contrast to 49 with foodborne, were found in the Oxford, England, outbreak in 1950 (11), and four persons with contact cases, versus three with foodborne, were reported in the Mangakino, New Zealand, outbreak in 1957 (14). In the 1962 outbreak in
St. Louis, Mo., 1 person was infected by contact with the index person, while 14 persons had foodborne infections (20). The index person in the Missouri City, Tex., outbreak in 1959 infected 5 persons by contact and 21 persons in his role as a kitchen employee (16). This sample is admittedly biased by the fact that the outbreaks cited were first recognized as foodassociated. Data of this kind are extremely limited, but it is evident that outbreaks do occur in which the number of persons infected by foodborne virus exceeds considerably the number infected by contact. The converse type of outbreak evidently has not been reported but may very well be observed in the future. At the very least, it appears that in appropriate circumstances food is a highly efficient vehicle for the transmission of infectious hepatitis.

Finally, there is a growing number of reports of hepatitis outbreaks associated with the consumption of shellfish. Seven such outbreaks are summarized in table 2. In only two of 
Table 2. Shellfish-associated outbreaks

\begin{tabular}{|c|c|c|}
\hline Location of outbreak ${ }^{1}$ & Dates of onset & $\begin{array}{l}\text { Number } \\
\text { exposed }\end{array}$ \\
\hline Sweden, 3 cities and 102 towns $(21,22)$ & Dec. 18, 1955-Jan. 26, 1956_...- & n.s.... \\
\hline Mississippi and Alabama (2S) & Jan. 1-Mar. 18, $1961 \ldots$ & n.s....- \\
\hline $\begin{array}{l}\text { New Jersey and New York }(17,24) \\
\text { Bronx, N.Y. (25) } \\
\text { Greater Philadelphia and Atlantic County, N.J. }(26 a))^{2} \\
\text { Connecticut and Rhode Island (26b) } \\
\text { Chapel Hill, N.C. (26c) }\end{array}$ & $\begin{array}{l}\text { Jan.-June 1961 } \\
\text { Oct. 6-10, 1962 } \\
\text { Sept. 29, 1963-Apr. 25, 1964. } \\
\text { Nov. 1, 1963-June 15, 1964. } \\
\text { Feb. 27-Mar. 5, 1964. }\end{array}$ & $\begin{array}{ll}\text { n.s. } \\
6 \\
\text { n.s. } \\
\text { n.s. }\end{array}$ \\
\hline
\end{tabular}

1 Numbers in parentheses are references.

Note: n.s.= not specified.

these were infections described which might have resulted from consumption of shellfish which had been cooked in any way. One person in the Mississippi and Alabama outbreak of 1961 had eaten oysters prepared by bringing milk and seasoning to a boil, adding the oysters, and cooking them just until the edges curled (23). One person in the Chapel Hill, N.C., outbreak in 1964 had eaten only steamed clams and oysters, but the steaming was intended just to be sufficient to make the shells easy to open (Dr. R. H. Levine, communicable disease control section, North Carolina State Board of Health, Raleigh, 1964, unpublished data).

The majority of these outbreaks evidently involved shellfish taken from waters closed to harvesting, either by persons who consumed the mollusks themselves $(23,25)$ or by commercial shellfishermen (23, 26a, 26c). The oysters implicated in the outbreak in Sweden in 1955 were probably safe at the time of harvest but had become contaminated while being held in a bay into which a latrine was emptied periodically (21). Clearly, the mode of contamination in these outbreaks differs significantly from those listed in table 1. Outbreaks in which shellfish are implicated may be regarded as both waterborne and foodborne, and preventive measures should probably be directed to breaking both segments of the chain of transmission. Waterborne outbreaks of infectious hepatitis are now legion (27) and they are not discussed further in this paper.

Shellfish-associated outbreaks of infectious hepatitis are also distinguished by relative ease of recognition. It has become increasingly common for patients with hepatitis to be asked if they have eaten raw shellfish in the past 60 days. This question was answered in the affirmative by 1,126 (7.1 percent) of the 15,694 adults with infectious hepatitis reported in the United States during the surveillance year April 1961 through April 1962 (28). The period in question coincides with a portion of only one of the outbreaks listed in table 2 , so it is obvious that few of these 1,126 cases were included in reported outbreaks. There is some question as to the proportion of the shellfish-associated infections which actually were caused by shellfishborne virus.

Data have been presented for 7,907 hepatitis patients during the epidemiologic year 1963-64 from whom histories were taken relative to raw shellfish consumption and to contact with persons having known cases during the 2 months previous to onset of symptoms. Cases in persons aged 20 years or over totaled 4,471, of which 475 or 10.6 percent were "shellfish positive." Among these 475, about 7 percent were also "contact positive," in contrast to 17.8 percent in the "shellfish-negative" group (29). Shellfish-associated outbreaks include primarily men living in coastal States, and these are the persons who consume the greatest quantities of raw shellfish. On the other hand, the limited number of foodborne outbreaks listed in table 1 does not show the increased seasonal incidence in winter, which typifies the disease in the population at large, while the shellfish-associated outbreaks tend to cluster from late fall through early spring.

It might be conjectured that the seasonal nature of shellfish consumption tends to accentuate the seasonal incidence of infectious hepatitis in 


\begin{tabular}{|c|c|c|}
\hline $\begin{array}{l}\text { Number } \\
\text { infected }\end{array}$ & Persons affected & Type and source of shellfish \\
\hline $\begin{array}{r}629 \\
\geq 84 \\
\geq 481 \\
\geq 258 \\
\geq \\
123 \\
3\end{array}$ & $\begin{array}{l}\text { Men, aged 25-60 years, from upper } \\
\text { socioeconomic groups. } \\
\text { Urban men, aged } 20 \text { years or over, from } \\
\text { upper socioeconomic groups. } \\
\text { Urban men.-. } \\
\text { Urban children, aged } 8 \text { to } 12 \text { years. } \\
\text { n.s. } \\
\text { n.s. } \\
\text { Men, aged } 26 \text {-36 years. }\end{array}$ & $\begin{array}{l}\text { Oysters held in Havstenssund Bay, Sweden. } \\
\text { Oysters from mouth of Pascagoula River, Miss. } \\
\text { Clams, principally from Raritan Bay, N.J. } \\
\text { Clams taken near Throggs Neck, Bronx. } \\
\text { Clams, principally from Atlantic County. } \\
\text { Clams, principally from Narrangansett Bay, R.I. } \\
\text { Clams and oysters from the area of Wrightsville Beach. }\end{array}$ \\
\hline
\end{tabular}

the population as a whole. However, if the seasonal incidence of infectious hepatitis in adults during the years 1961-64 is compared for the Atlantic and Gulf Coast regions with those for inland regions, there is no apparent support for this hypothesis (26d).

\section{Virus of Infectious Hepatitis}

The characterization of the virus of infectious hepatitis has been complicated by the problem of finding a suitable laboratory host system. Attempts to adapt the virus to laboratory animals have been unsuccessful (30). McCollum (31) has reviewed work with the virus in tissue cultures in a number of laboratories. Although several of the methods developed have appeared quite promising, considerable difficulty has been experienced in repeating them in laboratories other than the ones in which they were introduced.

As a result of the difficulties in finding suitable experimental host systems, most of what is known of the properties of the infectious hepatitis virus and its natural history has been learned from studies with human volunteers and reports of outbreaks. Feeding studies with human volunteers indicate that the virus is detectable in the stools of experimentally infected persons by the 25th day of incubation, or 2 to 3 weeks before onset of symptoms, and that it persists for at least 8 days (32), but probably not 3 weeks (4) after onset of jaundice. The virus was also present in the serum during the acute phase but could not be demonstrated in acute-phase urine or nasopharyngeal washings by Havens (33). Giles and co-workers (34) reported one case among 12 subjects given $5 \mathrm{ml}$. orally of urine, which was taken on the first day of jaundice. These data are necessarily limited; but they do suggest the period during which an infected foodhandler would be most likely to constitute a hazard, and they further indicato that fecal contamination, as suggested by Havens and Paul (5), is most likely to be the proximate source of virus in foods involved in outbreaks.

As discussed previously, the records of a number of infectious hepatitis outbreaks indicate that the virus may in some instances be more efficiently disseminated in foods than by direct person-to-person contact. In such circumstances, the stability of the agent when outside its natural host is not at issue. However, the stability of this virus has attracted a good deal of attention. Two cases were described previously in persons who had eaten only contaminated shellfish after limited cooking. Acid stability of the agent is also suggested, since in the 1962 outbreak in St. Louis, Mo., the virus must have remained infectious at least overnight and perhaps 36 hours in the refrigerator in orange juice (20). The $\mathrm{pH}$ of the orange juice was probably in the range of 3.5 to 4.0.

The shellfish implicated in the Chapel Hill, N.C., outbreak in 1964 had been held at room temperature for at least 3 days before being eaten by two of the three persons who became infected, and one of these persons ate them only after they had also been steamed to a limited extent (26c). Some of the data suggest that the virus might survive at least low-temperature, long-time pasteurization in milk ( 30 minutes at $145^{\circ}$ F.), and the absence of foods cooked or heated subsequent to contamination from the list in table 1 would only be evidence to the con- 
trary if it could be shown that cooked foods were given equal consideration as vehicles for the virus in outbreaks.

\section{Properties Shared With Others}

Although knowledge of the etiology and epidemiology of the disease is limited, some or all of the characteristics imputed to the virus of infectious hepatitis are known to be shared by a number of better-studied viruses. In particular, virtually all of the properties cited have been reported for at least some members of the enterovirus group. The enteroviruses are typically transmitted by a rectal-oral circuit and may be found in sewage (35). The polioviruses, which are members of the group, have been shown to be shed in feces for a median period of 5 weeks following natural infection or oral vaccination (.36). Polioviruses have been reported to retain infectivity after 60 minutes at $65^{\circ} \mathrm{C}$. $(37)$, and at $37^{\circ} \mathrm{C}$. for 3 hours at $\mathrm{pH} 2$ (36). Model studies have indicated that poliovirus type 3 (.38) and Coxsackie virus type B5 (39) might be recovered from shellfish taken from contaminated water, and that the viruses were much more stable within the mollusks than in the surrounding water. Coxsackie virus type B4 and ECHO type 9 have been isolated from oysters taken 4 miles from a point where raw sewage was being discharged into a river (40).

The foregoing has not been intended to demonstrate that the agent of infectious hepatitis is an enterovirus. The fact that the peak seasonal incidence of infectious hepatitis in the temperate zones occurs in winter and spring (5), while that of the enteroviruses occurs in summer and fall (.36), rather suggests the contrary. However, it has been shown that the known properties of the infectious hepatitis virus that are germane to its transmission in foods are shared by a number of other viruses infectious for humans. Among the human enteroviruses, a number of types frequently cause clinical illnesses less distinctive than infectious hepatitis. There are large numbers of foodborne illnesses, with symptoms compatible with those of enterovirus infection, in which it has not been possible to demonstrate a bacterial etiologic agent (41). It is therefore likely that infectious hepatitis is not unique in its propensity for transmission in foods, but rather that the 22 foodborne outbreaks described may be indications of what can be expected if other outbreaks of foodborne illness are investigated with viruses in mind.

\section{Summary}

A review of 22 food-associated outbreaks of infectious hepatitis which occurred from 1943 to 1964 included 7 in which shellfish were incriminated as the vehicle of transmission, while the rest were attributed to a variety of other foods. A majority of the foods implicated had not been cooked, but it seems that the virus is sufficiently stable to withstand limited heating and that a greater number of cooked foods might have been included if more investigations had been conducted with this in mind.

Reports of what is known of the virus of infectious hepatitis indicate that most of the properties of this agent which may apply to transmission in foods have also been described for other viruses infectious for man. This information may therefore serve as a model for the study of outbreaks of other foodborne virus diseases.

\section{REFERENCES}

(1) Brown, G. C.: The possible significance of milk and water in the spread of virus infections. Amer J Public Health 39: 764-771, June 1949.

(2) Berg, G.: The food vehicle in virus transmission. Health Lab Sci 1: 51-59, January 1964.

(3) Lemon, H. M.: Food-borne viruses and malignant hemopoietic diseases. Bact Rev 28: 490-492, December 1964.

(4) Havens, W. P., Jr.: Infectious hepatitis. Medicine $27: 279-326$, September 1948.

(5) Havens, W. P., Jr., and Paul, J. R.: Infectious hepatitis and serum hepatitis. In Viral and Rickettsial Infections of Man, edited by T. M. Rivers and F. L. Horsfall, Jr. J. B. Lippincott Co., Philadelphia, 1959, pp. 570-591.

(6) Gordon, J. E., editor: Control of communicable diseases in man. Ed. 10. American Public Health Association, New York, 1965, p. 115.

(7) Hiscock, I. V., and Rogers, O. F., Jr.: Outbreak of epidemic jaundice among college students. JAMA 78: 488-490, Feb. 18, 1922.

(8) Campbell : An outbreak of jaundice. Health Bull (Edinburgh) 2: 64-65, July 1943.

(9) Read, M. R., Bancroft, H., Doull, J. A., and Parker, R. F.: Infectious hepatitis-presumably food-borne outbreak. Amer J Public Health 36 : 367-370, April 1946. 
(10) Murphy, W. J., Petrie, L. M., and Work, S. D., Jr. : Outbreak of infectious hepatitis apparently milk-borne. Amer J Public Health 36: 169173, February 1946.

(11) Ballance, G. A. : Epidemic of infective hepatitis in an Oxford College. Brit Med J 1: 10711074, May 8, 1954.

(12) Kaufmann, G. G., Sborov, V. M., and Havens, W. P.: Outbreak of infectious hepatitis-presumably food-borne. JAMA 149 : 993-995, July $12,1952$.

(13) Clark, W., Sacks, D., and Williams, H.: An outbreak of infectious hepatitis on a college campus. Amer J Trop Med 7 : 268-279, May 1958.

(14) Seddon, J. H. : An epidemiological survey of infectious hepatitis in a country town. New Zeal Med J 60: 55-60, February 1961.

(15) McCollum, R. W.: An outbreak of viral hepatitis in the Mediterranean fleet. Milit Med 126: 902-910, December 1961.

(16) Dull, H. B., Doege, T. C., and Mosley, J. W. : An outbreak of infectious hepatitis associated with a school cafeteria. Southern Med J 56: 475480, May 1963.

(17) Dougherty, W. J., and Altman, R.: Viral hepatitis in New Jersey 1960-1961. Amer J Med 32 : 704716, May 1962.

(18) U.S. Public Health Service: Morbidity and mortality weekly report, vol 10, No. 26, July 7, 1961.

(19) Joseph, P. R., Millar, J. D., and Henderson, D. A. : An outbreak of hepatitis traced to food contamination. New Eng J Med 273: 188-194, July 1965.

(20) Eisenstein, A. B., Aach, R. D., Jacobsohn, W., and Goldman, A.: An epidemic of hepatitis in a general hospital. Probable transmission by contaminated orange juice. JAMA 185: 171174, July 20, 1963.

(21) Roos, B.: Hepatitepidemi, spridd genom ostron. (Hepatitis epidemic transmitted by oysters.) Svensk Lakartidn 53: 989-1003, Apr. 20, 1956.

(22) Gard, S.: In Hepatitis Frontiers [discussion]. Little, Brown \& Co., Boston, 1957, pp. 241-243.

(23) Mason, J. O., and McLean, W. R. : Infectious hepatitis traced to the consumption of raw oysters. An epidemiologic study. Amer J Hyg 75: 90111, January 1962.

(24) U.S. Public Health Service: Morbidity and Mortality Weekly Report, vol. 10, No. 17, May 5, 1961.

(25) U.S. Public Health Service: V. Infectious hepatitis possibly due to raw clams. Communicable Disease Hepatitis Surveillance Report No. 14, Feb. 15, 1963, p. 8.

(26) U.S. Public Health Service: IV. Shellfish-associated infectious hepatitis. Communicable Disease Hepatitis Surveillance Report No. 19,
June 30, 1964, (a) pp. 30-32; (b) pp. 32-34; (c) pp. $35-36$; (d) pp. 12-13.

(27) Mosley, J. W.: Waterborne infectious hepatitis. New Eng J Med 261 : 703-708, Oct. 1, 1959 ; 748 753, Oct. 8, 1959.

(28) U.S. Public Health Service: III. One year of adult surveillance through April 1962. Communicable Disease Hepatitis Surveillance Report No. 11, June 4, 1962, p. 4.

(29) U.S. Public Health Service: IV. Shellfish-associated hepatitis: Techniques for detecting epidemics. Communicable Disease Hepatitis Surveillance Report No. 21, Dec. 31, 1964, pp. 25-27.

(\$0) Rhodes, A. J., and van Rooyen, C. E.: Infectious hepatitis. In Textbook of Virology. Williams \& Wilkins Co., Baltimore, 1962, pp. 277-283.

(31) McCollum, R. W.: The elusive etiologic agents of viral hepatitis. Amer J Public Health 53: 1630-1634, October 1963.

(32) Krugman, S., et al.: Infectious hepatitis: ,detection of virus during the incubation period and in clinically inapparent infection. New Eng J Med 261: 729-734, Oct. 8, 1959.

(33) Havens, W. P., Jr.: Period of infectivity of patients with experimentally induced infectious hepatitis. J Exp Med 83 : 251-258, March 1946.

(34) Giles, J. P., Liebhaber, H., Krugman, S., and Lattimer, C.: Early viremia and viruria in infectious hepatitis. Virology 24: 107-108, September 1964.

(35) Clarke, N. A., and Kabler, P. W.: Human enteric viruses in sewage. Health Lab Sci 1: 44-50, January 1964.

(36) Plotkin, S. A., Carp, R. I., and Graham, A. F.: The polioviruses of man. Ann NY Acad Sci 101 : 357-389, Nov. 30, 1962.

(s7) Medearis, D. N., Jr., Arnold, J. H., and Enders, J. F.: Survival of polioviruses at elevated temperatures $\left(60^{\circ}-75^{\circ}\right.$ C. $)$. Proc Soc Exp Biol Med 104: 419-423, July 1960.

(\$8) Hedstrom, C. E., and Lycke, E.: An experimental study on oysters as virus carriers. Amer J Hyg 79 : 134-142, March 1964.

(39) Atwood, R. P., Cherry, J. D., and Klein, J. O.: Clams and viruses: studies with Coxsackie B5 virus. Communicable Disease Center Hepatitis Surveillance Report No. 20, Sept. 30, 1964, pp. $26-30$.

(40) Metcalf, T. G., and Stiles, W. C.: The accumulation of enteric viruses by the oyster, Crassostrea virginica. J Infect Dis 115: 68-76, February 1965.

(41) Dauer, C. C.: 1960 summary of disease outbreaks and a 10-year résumé. Public Health Rep 76 : 915-922, October 1961. 